OPEN ACCESS

Edited by:

Hai Xu,

Tianjin University, China

Reviewed by:

Junyi Ge,

Institute of Vertebrate Paleontology and Paleoanthropology (CAS), China Anchuan Fan,

University of Science and Technology of China, China

*Correspondence:

ZhongPing Lai

zhongping.lai@yahoo.com;

zhongping_lai@stu.edu.cn

${ }^{t}$ These authors have contributed

equally to this work

Specialty section:

This article was submitted to Quaternary Science, Geomorphology and Paleoenvironment, a section of the journal Frontiers in Earth Science

Received: 11 March 2020 Accepted: 11 June 2020 Published: 03 July 2020

Citation:

Xu X, Li H, Tang L, Lai Z, Xu G,

Zhang $X$ and Wang $Y$ (2020) Chronology of a Holocene Core From the Pearl River Delta in Southern China. Front. Earth Sci. 8:262. doi: 10.3389/feart.2020.00262

\section{Chronology of a Holocene Core From the Pearl River Delta in Southern China}

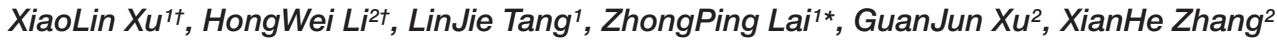 \\ and YiXuan Wang ${ }^{3}$
}

${ }^{1}$ Institute of Marine Sciences, Guangdong Provincial Key Laboratory of Marine Biotechnology, Shantou University, Shantou, China, ${ }^{2}$ Guangdong Geological Survey Institute, Guangzhou, China, ${ }^{3}$ Salt Lake Chemistry Analysis and Test Center, Qinghai Institute of Salt Lakes, Chinese Academy of Sciences, Xining, China

Establishing a reliable chronological framework for sediments is crucial to the reconstruction of evolution process of estuarine delta, and the study of regional paleoenvironmental history, e.g., sea level fluctuations due to global climatic changes. High resolution chronology is still very limited for Holocene sediments in the Pearl River delta (PRD) in southern China. This study tries to construct a detailed chronology for core DA of $37.7 \mathrm{~m}$ in depth by using luminescence (seven samples) and radiocarbon (fourteen samples) dating techniques. Our results indicate that both luminescence and radiocarbon dating methods are suitable for the Holocene sediments in the PRD and that sediments of core DA were deposited during 7.3-0.18 ka. The ${ }^{14} \mathrm{C}$ age is generally older than the OSL age for the sediment at the similar depths, and the age difference increased from $0.45 \mathrm{ka}$ at the depth of $21 \mathrm{~m}$ to $0.98 \mathrm{ka}$ at the depth of $35 \mathrm{~m}$. The reason that ${ }^{14} \mathrm{C}$ ages are relatively older might be caused by the carbon-reservoir effect which requires further study. The sedimentation rate increased from $3.74 \mathrm{~m} / \mathrm{ka}$ during $7.3-2 \mathrm{ka}$ to $7.92 \mathrm{~m} / \mathrm{ka}$ in the last $2 \mathrm{ka}$. The appearances of rusty stains in upper unit of the core revealed that the water level was gradually falling. After the formation of underwater sand body at about $2 \mathrm{ka}$, the sediment was subject to continuous shifting between submergence and exposure.

Keywords: optically stimulated luminescence dating, radiocarbon dating, drilling core, Holocene environment, the Pearl River delta in southern China

\section{INTRODUCTION}

As the product of complex dynamic actions in littoral zones, estuarine delta is a key area in studying the regional paleoenvironmental history, and provides an important window to understand the coupling interplay among eustasy, climate, and tectonics on the deltaic evolution (e.g., Hori et al., 2001; Saito et al., 2001; Sarkar et al., 2009; Tang et al., 2010; He et al., 2017; Pennington et al., 2017; Li et al., 2018; Bomer et al., 2019; Pleuger et al., 2019; Xu et al., 2019). To obtain such information, accurate and reliable chronology is of crucial importance. Radiocarbon dating (e.g., Hori et al., 2001; Nageswara Rao et al., 2012; Xu et al., 2019) and luminescence dating (e.g., Shen and Mauz, 2012; Sugisaki et al., 2015; Nian et al., 2018; 
Wang F. et al., 2018; Wang Z. H. et al., 2018; Wang et al., 2019) have been widely used for dating the Holocene deltaic sediments.

The Pearl River delta (PRD) is one of the biggest estuarine deltas in China. Based on seismic reflection profiles and borehole data, studies on the Quaternary deposits showed that the PRD has experienced a major transgressive-regressive cycle during the Holocene, and formed a corresponding terrestrial unit and a marine unit (Fyfe et al., 1997; Owen et al., 1998; Zong et al., 2009b; Yu, 2017). Zong et al. (2009a) proposed an evolution model of PRD for the time interval of the last 9 cal ka BP, based on lithological characteristics, microfossil assemblages and 34 new or published radiocarbon dates of 35 cores drilled from north to the south of PRD, together with the archaeological and historical documents. They showed that three driving factors, including sea level changes, monsoon-drive discharge and human activities, played important roles in different stages of delta formation, respectively. Ten ${ }^{14} \mathrm{C}$ ages of core PRD11 in the central PRD showed that the regional Holocene stratum was formed during 8.6 to $0.4 \mathrm{cal} \mathrm{ka} \mathrm{BP}$, and that the sedimentation rate decreased from $1.74 \mathrm{~m} / \mathrm{ka}$ (8.6 to $4.7 \mathrm{cal} \mathrm{ka} \mathrm{BP})$ to $0.72 \mathrm{~m} / \mathrm{ka}(4.7-0.4 \mathrm{cal}$ ka BP) (Liu et al., 2016). Hu et al. (2013) obtained ten AMS ${ }^{14} \mathrm{C}$ ages, ranging from 8.0 to $1.2 \mathrm{cal} \mathrm{ka} \mathrm{BP}$, on mollusk fossils for a 6 $\mathrm{m}$-thick mud layer with occasional shell-rich intervals from core B2/1, which was located in the mouth of the Pearl River Bay. They also reported an event of enhanced sediment weathering intensity during the last $2.5 \mathrm{cal} \mathrm{ka} \mathrm{BP}$. Again by radiocarbon dating on core HKUV11 from a near-shore location of the northern South China Sea, seven marine shell ages revealed that the stratum above the hard and mottled sandy-clayey silt was formed during 9.2-1.6 cal ka BP, with a stable sedimentation rate of $1.8 \mathrm{~m} / \mathrm{ka}$ (Wu et al., 2017).

From the above mentioned studies, it seems that an ideal chronological framework can be obtained in most radiocarbon studies. However, problems also exist in these previous studies. The age data density of some sediment cores is relatively low. For instance, core PK16 (20 m long) in Zong et al. (2009a) had only three ages. Core B2/1 (10 m long) had the best dating density with only ten ${ }^{14} \mathrm{C}$ ages (Hu et al., 2013). In a few studies, the radiocarbon ages from the top part of the cores were relatively older than expected (e.g., Hu et al., 2013; Wu et al., 2017). Some other studies reported that the ${ }^{14} \mathrm{C}$ dates from the surface samples were abnormally old by up to $2 \mathrm{ka}$, and that these dating samples might be the allochthonous materials transported by flow and tides (Yim et al., 2006; Kong et al., 2014). Study on the natural $\Delta^{14} \mathrm{C}$ data of river water from carbonate-rich PRD revealed that PRD could release negative particulate organic carbon (POC) that represented old carbon from deeper sediments and sedimentary rocks, which had significant effect on the organic carbon ages (Liu et al., 2017). For instance, the $\Delta^{14} \mathrm{C}$-POC value obtained from the Xijiang River in the dry season corresponds to a radiocarbon age of 2820 a BP (Liu et al., 2017).

Compared with the numerous ${ }^{14} \mathrm{C}$ dating ages reported, there are only a few case studies using optical stimulated luminescence (OSL) technique in the PRD. In order to determine the position of ancient coastal lines, Peng et al. (2014) recognized that the marine muddy-silt outcrop, deposited on a wave-cut platform in the central PRD, was formed at 5.5-5.0 ka, based on three samples by fine-grained quartz OSL dating. Using seven cores from Dongjiang River sub-delta, Guo et al. (2013) built a relatively rough chronological framework of late Quaternary sediments based on 13 fine-grained quartz OSL ages and 13 radiocarbon ages, and pointed out that most of the OSL ages are consistent with ${ }^{14} \mathrm{C}$ ages in Holocene stratum. But this claim was based on only a pair of OSL and ${ }^{14} \mathrm{C}$ ages from similar depths. They also concluded that the marine transgression inundated almost the whole Dongjiang River sub-delta during the Holocene transgression event (ages $<8 \mathrm{ka}$ ).

Although there are many stratigraphic studies and radiocarbon dating data of the Holocene sediments in the $\mathrm{PRD}$, the application of OSL dating and the comparative analysis of OSL and ${ }^{14} \mathrm{C}$ techniques is still limited. This study attempts to build a high resolution chronological framework for a 37.7m-long core drilled from southern PRD using both OSL (seven samples) and radiocarbon dating (fourteen samples).

\section{THE STUDIED AREA AND SAMPLING}

\section{The Studied Area}

The Pearl River delta is located in the central of Guangdong province, southeast coast of China, covering an area of $8601 \mathrm{~km}^{2}$. It is composed of deltas of Dongjiang River, Xijiang-Beijiang River and Tanjiang River (Huang et al., 1982). The neotectonic movement in the PRD is mainly characterized by faulting and differential uplift of fault blocks (Huang et al., 1982; Yao et al., 2008). The main fault zones have been active during the Quaternary (Liu, 1994). To some extent, the faults controlled the topography of the basement and river direction of the delta (Yu et al., 2016). Since the Holocene, the fault activity in the PRD became weaker, and the river system basically inherited the pattern before the last marine transgression (Yao et al., 2008). In geomorphic features, the north, east, west sides of delta are surrounded by mountains and hills, and the south is facing the South China Sea (Figure 1). The delta plain is also dotted with hilly platforms, while the delta front has low hills. The basement is characterized by gentle undulation, two parallel ridges and valleys and checkerboard pattern (Huang et al., 1982). The average sedimentary thickness of Quaternary strata was only about 25.1 $\mathrm{m}$, with the Xijiang River and Beijiang River deltas relatively thicker (25.6 $\mathrm{m}$ on average; Huang et al., 1982).

\section{Core DA and Sampling}

Core DA was drilled from a sand bar, located in the Xijiang River estuary of western PRD (Figure 1), and had a length of $37.7 \mathrm{~m}$. The core was drilled by direct mud rotary with $>90 \%$ recovery rate. The sediments are mainly composed of clay and silt, mixed with thin layers or lens of fine sand with horizontal beddings (Figure 2), and can be divided into three units. From bottom to top: Unit $1(37.7-22.52 \mathrm{~m})$ shows light gray silt with a small amount of clay; Unit $2(22.52-18.0 \mathrm{~m})$ is a dark gray silt mixed with thin layers of clay, and with thicker sandy layers occurring at the depths of 20.00-19.70 and 19.00-18.10 m; and Unit 3 (18.0$5.0 \mathrm{~m}$ ) is brown clay mixed with silt. The upper five meters are reworked materials by human re-filling. 


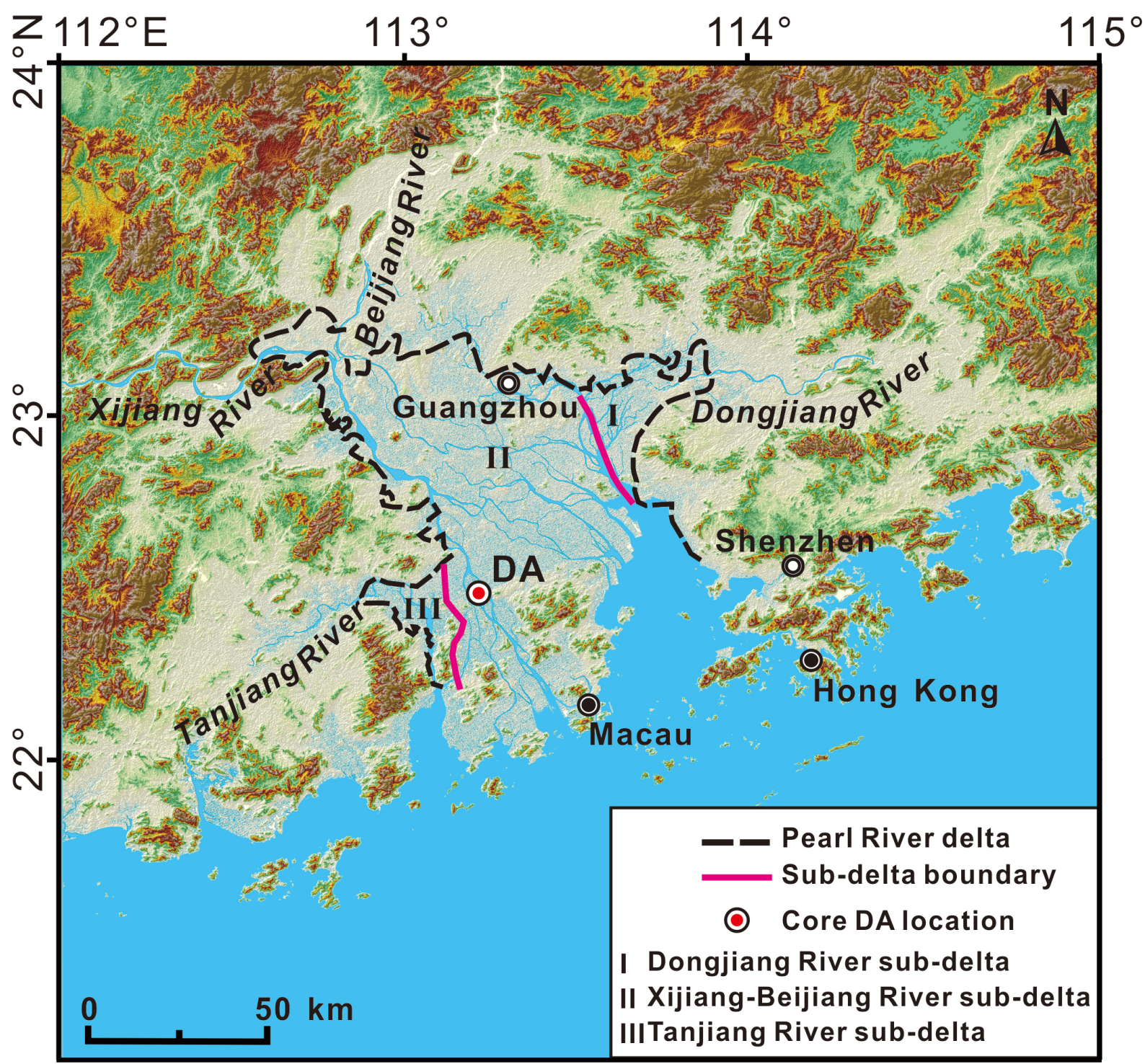

FIGURE 1 | Topographic characteristics of the Pearl River delta (PRD) and location of core DA. The PRD can be divided into Dongjiang River sub-delta (zone I), Xijiang-Beijiang River sub-delta (zone II) and Tanjiang River sub-delta (zone III). Core DA is located in the south of zone II.

The core contains many rust stains (Figure 2 ). The mild rust stain first occurred at the depth of $25.55 \mathrm{~m}$ and the moderate rust stain first occurred at $24.40 \mathrm{~m}$. The moderate rust stain was found at $16.85 \mathrm{~m}$ with a thickness of about $3 \mathrm{~cm}$. The frequency of upward rust stains increased after the occurrence of thin layer sand with severe rust stains at $13.80 \mathrm{~m}$.

\section{MATERIALS AND METHODS}

\section{OSL Dating}

\section{Sample Preparation}

Seven samples were dated. All operations followed the routines of luminescence dating procedures (Lai, 2010), and were carried out under subdued red light in the laboratory. The out layer of the sample that might have been light-exposed was removed, and the remaining samples were successively treated to remove carbonate and organic matter with $10 \% \mathrm{HCl}$ and $30 \% \mathrm{H}_{2} \mathrm{O}_{2}$. The samples were then wet sieved to obtain $38-63$ or $90-125$ $\mu \mathrm{m}$ grain size particles, depending on availability. Samples with a grain size of $90-125 \mu \mathrm{m}$ were then etched with $40 \% \mathrm{HF}$ for $\sim 60$ min to remove feldspar minerals, while samples of 38-63 $\mu \mathrm{m}$ were treated with $35 \% \mathrm{H}_{2} \mathrm{SiF}_{6}$ for about $2-3$ weeks, and both were then washed with $10 \% \mathrm{HCl}$ for about $30 \mathrm{~min}$ to remove the chloride precipitation generated during the reaction. To ensure the quartz purity, infrared stimulated luminescence (IRSL) measurement was conducted. Finally, the quartz sample was uniformly coated as a mono-layer on the central part ( $\sim 0.7 \mathrm{~cm}$ diameter $)$ of stainless-steel discs $(\sim 0.97 \mathrm{~cm}$ diameter $)$ by silicone oil. 

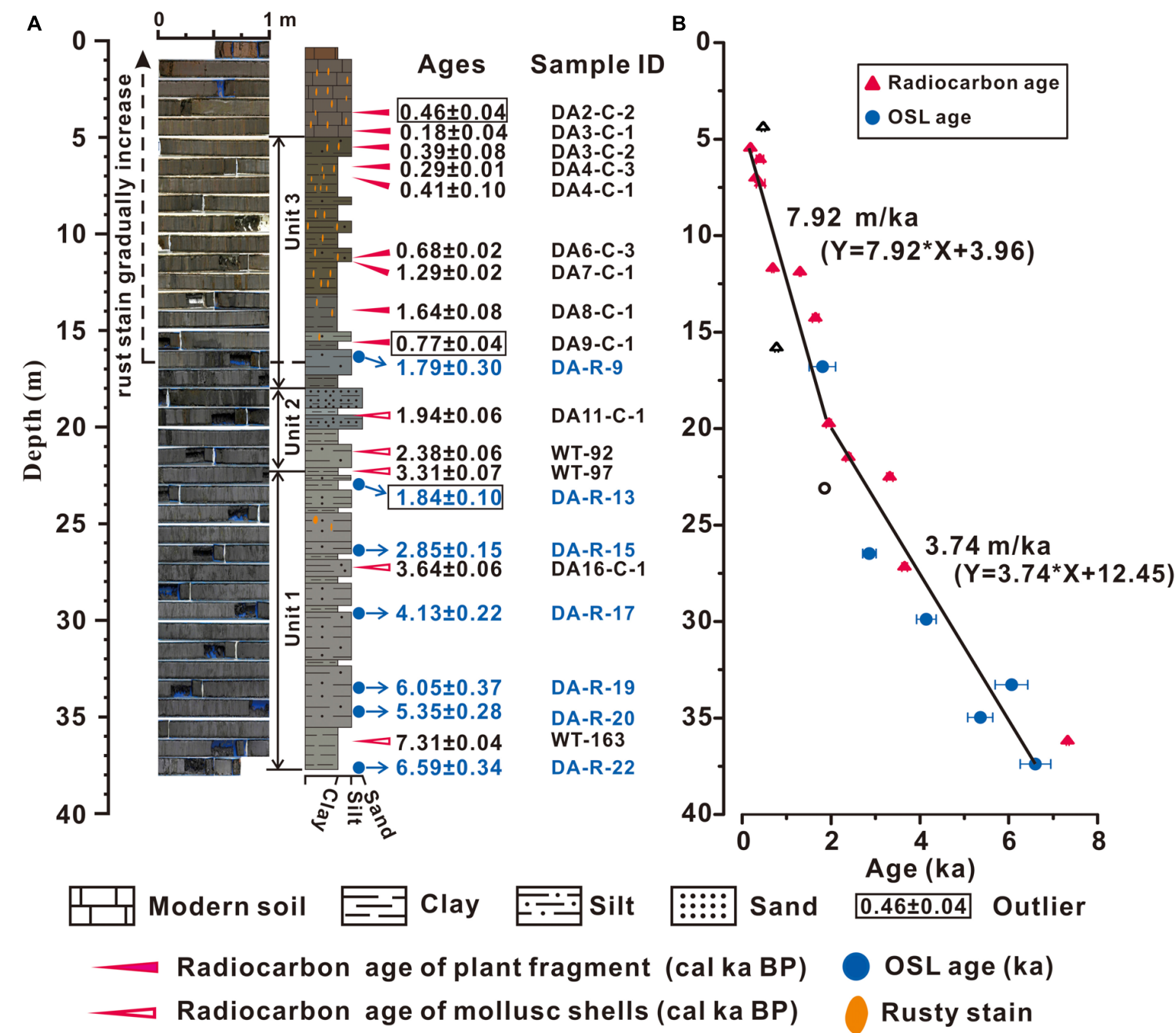

FIGURE 2 | Profile of core DA showing (A) the lithology, OSL and radiocarbon ages; (B) the age-depth model. The color of core profile represents the color observed from field. The hollow triangle and circle in $\mathbf{( B )}$ represent the outlier age of ${ }^{14} \mathrm{C}$ and OSL, respectively.

\section{Equivalent Dose $\left(D_{e}\right)$ Determination}

OSL measurements were performed on a Risø TL/OSL-DA-20 reader equipped with a ${ }^{90} \mathrm{Sr} /{ }^{90} \mathrm{Y}$ beta source. Quartz signals were stimulated by a blue light $(\lambda=470 \pm 20 \mathrm{~nm})$ for $40 \mathrm{~s}$ at $130^{\circ} \mathrm{C}$. The signal was recorded by $9235 \mathrm{QA}$ photomultiplier through a $7.5 \mathrm{~mm}$ Hoya U-340 filter. The equivalent dose $\left(D_{e}\right)$ was determined by a combination of single aliquot regenerativedose (SAR) protocol (Murray and Wintle, 2000) and standard growth curve (SGC) protocol (Roberts and Duller, 2004; Lai, 2006). The experiment results of preheat plateau test and dose recovery test from $\mathrm{Yu}$ (2017) showed that it is feasible to choose the preheat temperature of $260^{\circ} \mathrm{C}$ with duration of $10 \mathrm{~s}$ during the SAR and SGC protocol for dating deltaic samples from PRD. Therefore, the preheat temperature for regeneration doses is chosen to be of $260^{\circ} \mathrm{C}$ for $10 \mathrm{~s}$, and the preheating temperature for test doses $220^{\circ} \mathrm{C}$ for $10 \mathrm{~s}$. Four to six aliquots of each sample were measured by using SAR protocol and an SGC curve was established for each sample.
To determinate the natural signal $\left(\mathrm{L}_{\mathrm{N}}\right)$ and the test dose signal $\left(\mathrm{T}_{\mathrm{N}}\right)$, another six to twelve aliquots under the same measurement parameters were measured. Each value of $\mathrm{L}_{\mathrm{N}} / \mathrm{T}_{\mathrm{N}}$ was projected into the SGC curve to obtain a $D_{e}$ value. The final $D_{e}$ value is the average of all $D_{e}$ values measured by both SAR and SGC protocols.

\section{Dose Rate Determination}

Neutron activation analysis (NAA) was used to obtaining U, Th, and $\mathrm{K}$. The cosmic ray dose was calculated based on the altitude, geographical location and depth of the samples (Prescott and Hutton, 1994). The contribution of alpha particles was also taken into account in the quartz grains of $38-63 \mu \mathrm{m}$ with a coefficient of $0.035 \pm 0.003$ (Lai et al., 2008). The measured moisture content was used, with an uncertainty of $\pm 8 \%$ in the age calculation by considering seasonal variation of precipitation in the studied area. The dose rates and final ages were calculated on the website program of DARC (Durcan et al., 2015). 


\section{Radiocarbon Dating}

A total of 14 radiocarbon samples were collected from core DA. Eight plant fragment samples collected at depths of 4.43, $5.51,6.09,7.06,11.72,11.91,14.30$, and $15.84 \mathrm{~m}$ were sent to Peking University. One plant fragment collected at the depth of $7.34 \mathrm{~m}$ and five mollusk shells at depths of 19.76, 21.51, 22.52, 27.18, and $36.18 \mathrm{~m}$ were sent to the Beta Analytic Radiocarbon Dating Laboratory. Based on the difference of sample properties, the IntCal04 (Reimer et al., 2004) and the Marine13 (Reimer et al., 2013) calibration curves were chosen for the calibration of plant fragment samples and mollusk shells samples, respectively. Calibrated ages were obtained by using the procedure OxCal v3.10 (2).

\section{RESULTS}

\section{Luminescence Characteristics and OSL Ages}

Most samples showed good luminescence behavior. OSL growth curves and decay curves of represented aliquot for samples DA-R$09(90-125 \mu \mathrm{m})$ and DA-R-20 $(38-63 \mu \mathrm{m})$ are shown in Figure 3.
As can be seen from the decay curves, the OSL signal rapidly decreases to the background value within $1 \mathrm{~s}$, indicating that quartzes are mainly composed of fast components. The recycle ratio of sample DA-R-09 (1.00-1.05) and DA-R-20 (0.98-1.07) indicate that the correction of test dose for sensitivity changes is ideal. The ratio of zero dose to natural dose $\left[\left(\mathrm{L}_{0} / \mathrm{T}_{0}\right) /\left(\mathrm{L}_{\mathrm{N}} / \mathrm{T}_{\mathrm{N}}\right)\right]$, sample DA-R-09 at 0.07-1.4\%, and DA-R-20 at $0.5-0.9 \%$ are all lower than the threshold of $5 \%$, indicating that the recuperation is negligible. Laboratory known-dose can also be recovered with $10 \%$ error.

The OSL dating results are listed in Table 1. OSL ages range from $6.59 \pm 0.34 \mathrm{ka}$ to $1.79 \pm 0.30 \mathrm{ka}$. Overall, the OSL ages increase with depth and conform to the general stratum sequences.

\section{Radiocarbon Ages}

The radiocarbon dating results are listed in Table 2 and Figure 2. The AMS ${ }^{14} \mathrm{C}$ ages range from $7,306 \pm 36 \mathrm{cal}$ a $\mathrm{BP}$ to $180 \pm 37 \mathrm{cal}$ a BP. Among them, Sample DA2-C-2 (462 $\pm 40 \mathrm{cal}$ a BP $)$ from the top might be re-deposited material. And Sample DA9C-1 (766 $\pm 38 \mathrm{cal} \mathrm{a} \mathrm{BP})$ at a depth of $15.84 \mathrm{~m}$ shows an abnormally young age, which may be due to the introduction
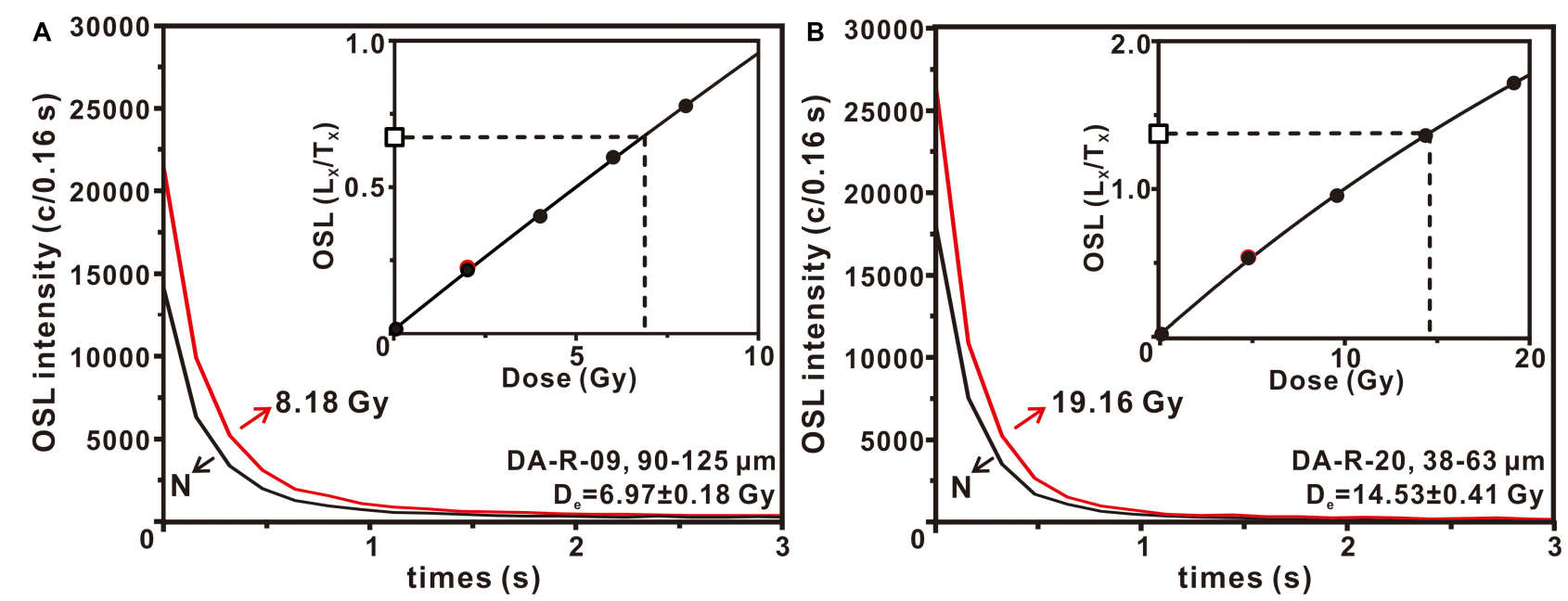

FIGURE 3 | Luminescence properties of sample DA-R-09 (A) and DA-R-20 (B). The black lines and red lines represent OSL decay curves of the natural signal and regeneration signal, respectively. The growth curves are shown in the set charts. Black cycles, regenerative doses; Red cycles, recycled doses; hollow square, natural doses.

TABLE 1 | OSL dating results from core DA.

\begin{tabular}{|c|c|c|c|c|c|c|c|c|c|c|}
\hline $\begin{array}{l}\text { Sample } \\
\text { ID }\end{array}$ & $\begin{array}{c}\text { Depth } \\
\text { (m) }\end{array}$ & $\begin{array}{c}\text { Grain size } \\
(\mu \mathrm{m})\end{array}$ & $\begin{array}{l}\text { Aliquot } \\
\text { number }\end{array}$ & $\begin{array}{c}K \\
(\%)\end{array}$ & $\begin{array}{c}\text { Th } \\
\text { (ppm) }\end{array}$ & $\begin{array}{c}\mathbf{U} \\
(\mathrm{ppm})\end{array}$ & $\begin{array}{c}\text { Moisture } \\
\text { (\%) }\end{array}$ & $\begin{array}{c}\text { Dose rate } \\
\text { (Gy/ka) }\end{array}$ & $\begin{array}{l}D_{e} \\
\text { (Gy) }\end{array}$ & $\begin{array}{l}\text { OSL age } \\
\text { (ka) }\end{array}$ \\
\hline DA-R-9 & 16.8 & $90-125$ & $6^{a}+12^{b}$ & $1.4 \pm 0.1$ & $11.8 \pm 0.3$ & $2.2 \pm 0.1$ & $28.8 \pm 8$ & $2.09 \pm 0.11$ & $3.7 \pm 0.6$ & $1.79 \pm 0.30$ \\
\hline DA-R-13 & 23.09 & $38-63$ & $4^{a}+6^{b}$ & $1.3 \pm 0.1$ & $15.9 \pm 0.4$ & $3.4 \pm 0.1$ & $27.4 \pm 8$ & $2.63 \pm 0.14$ & $4.8 \pm 0.1$ & $1.84 \pm 0.10$ \\
\hline DA-R-15 & 26.49 & $38-63$ & $4^{a}+6^{b}$ & $1.5 \pm 0.1$ & $14.1 \pm 0.4$ & $2.6 \pm 0.1$ & $33.1 \pm 8$ & $2.42 \pm 0.12$ & $6.9 \pm 0.1$ & $2.85 \pm 0.15$ \\
\hline DA-R-17 & 29.89 & $38-63$ & $4^{a}+6^{b}$ & $1.6 \pm 0.1$ & $14.5 \pm 0.4$ & $2.8 \pm 0.1$ & $31.6 \pm 8$ & $2.57 \pm 0.13$ & $10.6 \pm 0.1$ & $4.13 \pm 0.22$ \\
\hline DA-R-19 & 33.28 & $38-63$ & $4^{a}+6^{b}$ & $1.4 \pm 0.1$ & $12.1 \pm 0.3$ & $2.7 \pm 0.1$ & $28.6 \pm 8$ & $2.32 \pm 0.12$ & $14.0 \pm 0.4$ & $6.05 \pm 0.37$ \\
\hline DA-R-20 & 34.98 & $38-63$ & $4^{a}+12^{b}$ & $1.6 \pm 0.1$ & $15.9 \pm 0.4$ & $2.7 \pm 0.1$ & $30.4 \pm 8$ & $2.62 \pm 0.14$ & $14.0 \pm 0.2$ & $5.35 \pm 0.28$ \\
\hline DA-R-22 & 37.39 & $38-63$ & $4^{a}+12^{b}$ & $1.8 \pm 0.1$ & $17.6 \pm 0.5$ & $3.1 \pm 0.1$ & $30.9 \pm 8$ & $2.92 \pm 0.15$ & $19.2 \pm 0.2$ & $6.59 \pm 0.34$ \\
\hline
\end{tabular}

The superscript "a" means aliquot numbers for SAR protocol and superscript "b" means aliquot numbers for SGC protocol. 
TABLE 2 | Radiocarbon dates from core DA.

\begin{tabular}{lccrc}
\hline Sample ID & Depth $(\mathbf{m})$ & Dating material & $\mathbf{1 4}^{\mathbf{C}}$ age (a BP) & $\begin{array}{c}\text { Calibrated age } \\
(\mathbf{2} \boldsymbol{\sigma} ; \mathbf{c a l} \mathbf{a} \mathbf{B P})\end{array}$ \\
\hline DA2-C-2 & 4.43 & Plant fragment & $365 \pm 30$ & $462 \pm 40$ \\
DA3-C-1 & 5.51 & Plant fragment & $330 \pm 30$ & $180 \pm 37$ \\
DA3-C-2 & 6.09 & Plant fragment & $185 \pm 20$ & $390 \pm 82$ \\
DA4-C-3 & 7.06 & Plant fragment & $235 \pm 20$ & $294 \pm 13$ \\
DA4-C-1 & 7.34 & Plant fragment & $350 \pm 30$ & $405 \pm 95$ \\
DA6-C-3 & 11.72 & Plant fragment & $730 \pm 25$ & $678 \pm 23$ \\
DA7-C-1 & 11.91 & Plant fragment & $1370 \pm 20$ & $1293 \pm 18$ \\
DA8-C-1 & 14.3 & Plant fragment & $1745 \pm 30$ & $1642 \pm 76$ \\
DA9-C-1 & 15.84 & Plant fragment & $875 \pm 25$ & $766 \pm 38$ \\
DA11-C-1 & 19.76 & Gastropod shell & $1990 \pm 30$ & $1938 \pm 58$ \\
WT-92 & 21.51 & Clam shell fragment & $2340 \pm 30$ & $2377 \pm 62$ \\
WT-97 & 22.52 & Oyster shell fragment & $3100 \pm 30$ & $3307 \pm 74$ \\
DA16-C-1 & 27.18 & Gastropod shell & $3400 \pm 30$ & $3638 \pm 62$ \\
WT-163 & 36.18 & Oyster shell fragment & $6400 \pm 30$ & $7306 \pm 36$ \\
\hline
\end{tabular}

of "new" carbon during burial or sample treatment. Samples DA2-C-2 and DA9-C-1 are treated as outliers, and will not be considered in the sedimentation rate discussion. Apart from these two samples, ${ }^{14} \mathrm{C}$ ages increase with depth and conform to the general stratum sequences.

\section{DISCUSSION}

\section{Assessment of the Radiocarbon and OSL Ages}

Previous studies compared ages by both radiocarbon and OSL dating methods on delta deposits. In studies of transgression events during the last glacial-interglacial period in coastal areas of eastern China, most ${ }^{14} \mathrm{C}$ dating ages fell into MIS 3 (e.g., Huang et al., 1982; Lin et al., 1989; Yim et al., 1990; Liu et al., 2009; Yin et al., 2016; Ye et al., 2017). These dating results could be problematic due to the limits of ${ }^{14} \mathrm{C}$ dating (Yim et al., 1990; Yi et al., 2013; Lai et al., 2014; Song et al., 2015; $\mathrm{Yu}$ et al., 2019), including the "reservoir effects" in coastal deposits (Stanley and Chen, 2000; Alves et al., 2015), the "new" carbon introduction during exposure (Yim et al., 1990), and the restricted theoretic upper limit to $50 \mathrm{ka}$ (Reimer et al., 2013) or pracitcal upper limit to only 25-30 ka (Lai et al., 2014; Song et al., 2015; Yu et al., 2019). The dating results of similar transgression deposits by other dating methods are mostly concentrated in MIS 5, such as OSL (e.g., Owen et al., 1998; Yi et al., 2013; Yu et al., 2017), or uranium-series dating (Yim et al., 1990).

For Holocene samples, most of the radiocarbon ages agree well with the OSL ages along the south Bohai Sea (Yi et al., 2013). In eastern PRD, Guo et al. (2013) found out that most of the Holocene ${ }^{14} \mathrm{C}$ ages were consistent with the OSL ages, but a few ${ }^{14} \mathrm{C}$ results were obviously younger. The radiocarbon results from incised valley of the Yangtze River delta are mostly not in stratigraphic order due to contamination by old carbon material, while the OSL ages shows better results (Nian et al., 2018).
In this study, OSL and ${ }^{14} \mathrm{C}$ ages are in general consistent with the stratigraphic order. The cross validation between OSL and ${ }^{14} \mathrm{C}$ ages only appeared below the depth of $16.8 \mathrm{~m}$. Therefore, we chose results that below $16.8 \mathrm{~m}$ in depth for detailed comparison. The linear curve fittings of both the calculated ${ }^{14} \mathrm{C}$ ages and OSL ages within the depths of 16.8 to $37.4 \mathrm{~m}$ show that the fitting results are satisfactory, with $\mathrm{R}$ square of 0.96 for ${ }^{14} \mathrm{C}$ ages, and 0.89 for OSL ages, respectively (Figure 4). According to the fittings, the ${ }^{14} \mathrm{C}$ ages are in general older than OSL ages, and the difference between these two dating results become larger with the increase of depth. The discrepancy can be directly reflected by taking the depth data into these two fitting equations for calculation. For instance, at the depth of $21 \mathrm{~m}$, the fitted OSL age is $1.81 \pm 0.14$ ka while the fitted ${ }^{14} \mathrm{C}$ age is $2.26 \mathrm{cal} \mathrm{ka} \mathrm{BP}$, with a difference of $0.45 \mathrm{ka}$. At the depth of $35 \mathrm{~m}$, the fitted OSL age is $5.87 \pm 0.46 \mathrm{ka}$ while the fitted ${ }^{14} \mathrm{C}$ age is $6.85 \mathrm{cal} \mathrm{ka} \mathrm{BP}$, with a difference of 0.98 $\mathrm{ka}$. The error of OSL age is taken from the average error of all the measured OSL ages.

Accurate radiocarbon dating of shells requires evaluation of local marine reservoir effect. In the study of marine reservoir correction for Southeast Asia, Southon et al. (2002) suggested that source waters entering the South China Sea were quite equilibrated with the atmospheric ${ }^{14} \mathrm{C}$, which gave low regional corrections (mean $\Delta \mathrm{R}$ values $=-25 \pm 20$ years) for the southern and central part of South China Sea, and that a probably $\Delta \mathrm{R}$ values lies between $-25 \pm 20$ years and $-149 \pm 7$ years for the South China coast. Compared with marine samples, mollusks from estuarine environment might have higher reservoir correction due to the additional carbonates input from bedrock and soil (Reimer, 2014). River water from carbonate-rich PRD can carry old carbon from deeper sediments and sedimentary rocks, and this hard water effect will cause abnormally higher ${ }^{14} \mathrm{C}$ ages (Liu et al., 2017). The fact that the ${ }^{14} \mathrm{C}$ ages are older than OSL ages in this study may be due to this carbon-reservoir effect. Meanwhile, carbon-reservoir effect in Holocene marine samples in the southwestern Pacific may have large $\Delta R$ values variation (maximum difference for about 410 years) during 8-5.4 ka, while the $\Delta \mathrm{R}$ values are close to modern values after $5.4 \mathrm{ka}$ (Hua et al., 2015). ${ }^{14} \mathrm{C}$ reservoir effect in Lake Bosten, northwestern China, trended to be greater in dry periods than in wet periods (Zhou et al., 2020). And this change might be related to the variable proportion of organic matter, which due to the different hydroclimatic conditions (Zhou et al., 2020). The reason for temporal difference in the ${ }^{14} \mathrm{C}$ reservoir effect in the PRD, as we found in core $\mathrm{DA}$, requires further study.

\section{Chronology of Core DA and the Paleoenvironmental Implications for the Pearl River Delta}

As shown in Figure 2, the sediment of core DA was deposited during 7.3-0.18 ka. Unit $1(37.73-22.52 \mathrm{~m})$ was deposited since 7.3-3.3 ka. This unit is composed of light gray silt, with rich broken bivalve shells and assemblages dominated by marine and estuary species. The rusty stain first appeared in this unit at depths $25.55-24.40 \mathrm{~m}$ with an age of about $3.0 \mathrm{ka}$. The appearance of rusty stain indicates that there might be a sea level dropping 


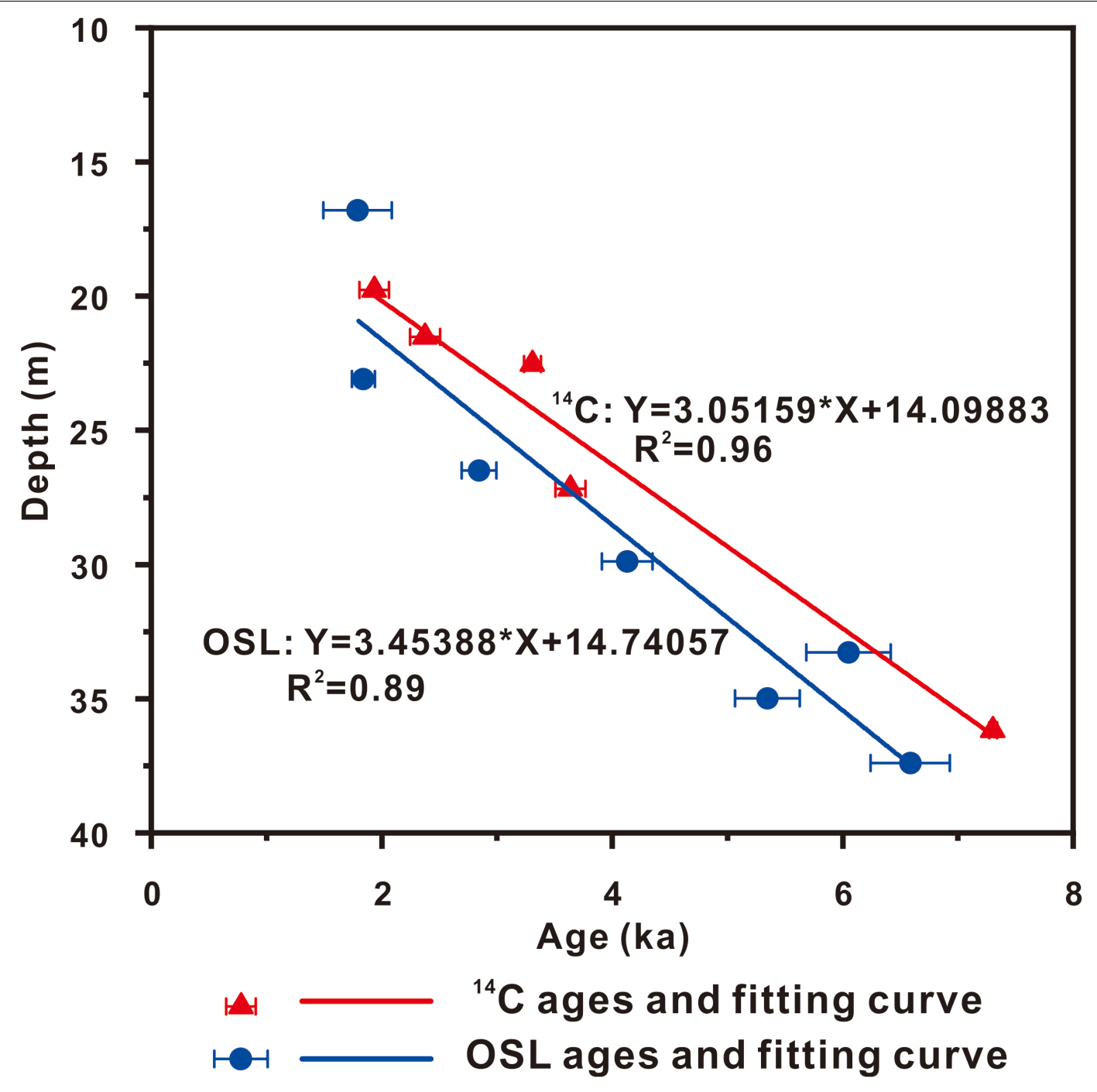

FIGURE 4 | Linear fitting curves for ${ }^{14} \mathrm{C}$ ages and OSL ages of core DA that obtained from depth 16.8 to $37.4 \mathrm{~m}$.

event. Study in the PRD have shown that the iron nodules appeared in marine deposits that formed in mid-Holocene, and it might due to the laterization process during later exposure (Huang et al., 1982). Others suggested that sea level was relatively high or stable during that time (Fang et al., 1991; Zong, 2004; Xiong et al., 2018).

Unit $2(22.52-18.0 \mathrm{~m})$ consists of dark gray silt with thin layers of clay, and two thick sandy layers appears at depths 20.00$18.10 \mathrm{~m}$. This unit represents two sets of underwater sand body and the formation age is about $3.3-2.0 \mathrm{ka}$. Unit 3 (18.0-5.0 $\mathrm{m}$ ) was deposited since about $2.0 \mathrm{ka}$. From $16.85 \mathrm{~m}$ upwards, the number of horizontal thin layer with rusty stain and iron nodules gradually increase and become common in sediments. The accumulation of $\mathrm{Fe}^{3+}$ indicates frequent fluctuation of water level. A study on cores from southern PRD also found out that after $2.5 \mathrm{ka}$ the weathering intensity sharply increased till the present day (Hu et al., 2013). Huang et al. (2018) presented similar results for samples from northern South China Sea, showing that intense chemical weathering in the northern shelf after 2 cal ka BP.

The sediment accumulation rate shows two-phase changes (Figure 2). During 7.3-2 ka (37.73-19.76 m), the rate is around $3.74 \mathrm{~m} / \mathrm{ka}$. It increases to around $7.92 \mathrm{~m} / \mathrm{ka}$ during the last 2 ka $(19.76-5.51 \mathrm{~m})$. The PRD is a composite delta formed by several rivers in a semi-closed bay, which may result in different rates in different locations (Fu et al., 2020). A study on the sedimentary rates in different locations of $\mathrm{PRD}$ revealed that the deltaic shoreline advanced and the sedimentation rate in the north and south wings of the central basin increased after about $4 \mathrm{ka}$ (Fu et al., 2020). Meanwhile, core PRD11, which was drilled from the central PRD, showed that the sedimentation rate decreased from $1.74 \mathrm{~m} / \mathrm{ka}(8.6-4.7 \mathrm{cal} \mathrm{ka} \mathrm{BP})$ to $0.72 \mathrm{~m} / \mathrm{ka}(4.7-$ 0.4 cal ka BP), due to the regional sedimentary environment changed into a alluvial plain setting in the later period (Liu et al., 2016). However, the statistical results of 92 cores in PRD revealed that the deposition center had shifted to the estuary area since 2.5 
$\mathrm{ka}$, and the sedimentary rate is $5.33 \mathrm{~m} / \mathrm{ka}$, compared to $2.15 \mathrm{~m} / \mathrm{ka}$ during 5.0-2.5 ka (Wei et al., 2011).

The extremely high accumulation rate since $2 \mathrm{ka}$ was also observed in the Yangtze River delta. For instance, core SD recorded an accumulation rate of $48 \mathrm{~m} / \mathrm{ka}$ in the last $2 \mathrm{ka}$ (Nian et al., 2018). The sediment trapping rate has increased from 99$113 \mathrm{Mt} / \mathrm{a}$ during 6-2 cal ka BP to $162 \mathrm{Mt} / \mathrm{a}$ in the last $2 \mathrm{ka}$ at the Yangtze River mouth (Wang Z. H. et al., 2018). Most studies linked this increase to the influence of intensified human activities, such as extensive influx of migrants and the expansion of agricultural land (Hori et al., 2001; Xu et al., 2012; Wang Z. H. et al., 2018). Other researches rather linked it to the paleocoastline change and the shift of deposition center (Feng et al., 2016; Nian et al., 2018). In the PRD, the sea level already reached the modern position and stayed stable during the last $2 \mathrm{ka}$ (Xiong et al., 2018). Zong et al. (2009a) and Huang et al. (2018) mentioned that after the sea level reached the present stable level, the whole delta was dominated by fluvial force, and the increased fluxes of river deposit was mainly contributed by the enhanced human activities. Core DA is located at the head area of the Xijiang River estuary. The acceleration of accumulation rate occurs after the formation of underwater sand body at 2 $\mathrm{ka}$. According to the characters of lithologic and assemblages of microfossils revealed by core DA (data unpublished), the regional environment changed from relatively open estuary bay to relatively closed one at $2 \mathrm{ka}$, which caused the reduction in outward sediment flux and trapping of a large amount of sediment. In this case, the high sedimentation rate since $2 \mathrm{ka}$ recorded by core DA could be interpreted as reflecting the enhanced fluvial force and the increased deposition flux, rather than the increased human activities.

\section{CONCLUSION}

Our results indicate that both luminescence and radiocarbon methods are applicable for dating the Holocene sediments in the PRD. However, ${ }^{14} \mathrm{C}$ age is generally older than the OSL age for samples from similar depths. The age difference increased from $0.45 \mathrm{ka}$ (OSL age is $1.81 \pm 0.14 \mathrm{ka}$ while ${ }^{14} \mathrm{C}$ age is $2.26 \mathrm{cal} \mathrm{ka} \mathrm{BP}$ )

\section{REFERENCES}

Alves, E., Macario, K., Souza, R., Pimenta, A., Douka, K., Oliveira, F., et al. (2015). Radiocarbon reservoir corrections on the Brazilian coast from prebomb marine shells. Q. Geochronol. 29, 30-35.

Bomer, E. J., Bentley, S. J., Hughes, J. E. T., Wilson, C. A., Crawford, F., and $\mathrm{Xu}, \mathrm{K}$. (2019). Deltaic morphodynamics and stratigraphic evolution of middle Barataria bay and middle Breton sound regions, Louisiana, USA: implications for river-sediment diversions. Estuar. Coast. Shelf Sci. 224, 20-33. doi: 10.1016/ j.ecss.2019.03.017

Durcan, J. A., King, G. E., and Duller, G. A. T. (2015). DRAC: dose rate and age calculator for trapped charge dating. Q. Geochronol. 28, 54-61. doi: 10.1016/j. quageo.2015.03.012

Fang, G. X., Li, P. R., and Huang, G. Q. (1991). Sea level changes in Zhujiang delta during the past 8000 years. Georaph. Res. 10, 1-11.

Feng, Z. B., Liu, B. H., Zhao, Y. X., Li, X. S., Jiang, L., and Si, S. K. (2016). Spatial and temporal variations and controlling factors of sediment accumulation in at the depth of $21 \mathrm{~m}$ to $0.98 \mathrm{ka}$ (OSL age is $5.87 \pm 0.46 \mathrm{ka}$ while ${ }^{14} \mathrm{C}$ age is $6.85 \mathrm{cal} \mathrm{ka} \mathrm{BP}$ ) at the depth of $35 \mathrm{~m}$. The reason for this discrepancy might be due to the carbon-reservoir effect. This requires further study.

The core DA was deposited during 7.3-0.18 ka. The first appearance of rust stains at about $3.0 \mathrm{ka}$ (depths 25.55-24.40 $\mathrm{m})$ may be caused by marine regression. Two sets of underwater sand bodies were formed during about 3.3-2.0 ka. And after that time, rust stains in horizontal thin layers gradually increased and become common, which indicate frequent fluctuation of water level. A significant increase in sedimentation rate was observed, from $3.74 \mathrm{~m} / \mathrm{ka}$ before $2 \mathrm{ka}$ to $7.92 \mathrm{~m} / \mathrm{ka}$ since $2 \mathrm{ka}$.

\section{DATA AVAILABILITY STATEMENT}

The datasets generated for this study are available on request to the corresponding author.

\section{AUTHOR CONTRIBUTIONS}

ZL was in over-all charge. XX and HL contributed to the analysis and writing work equally. LT, GX, and XZ finished the drilling and sampling work. YW was responsible to the OSL dating. All authors contributed to the article and approved the submitted version.

\section{FUNDING}

This research was supported by the special funds for Geological Survey Projects of the China Geological Survey Bureau (Grant No. 12120113066000), Special Project of Geological Hazard Control, Guangdong Province, China (Grant No. 2017201), and NSFC (Grant No. 41877438).

\section{ACKNOWLEDGMENTS}

We thank Prof. XiaoQiang Yang for help in dating work.

the Yangtze River estuary and its adjacent sea area in the Holocene, especially in the Early Holocene. Continent. Shelf Res. 125, 1-17. doi: 10.1016/j.csr.2016. 06.007

Fu, S. Q., Xiong, H. X., Zong, Y. Q., and Huang, G. Q. (2020). Reasons for the low sedimentation and slow progradation in the Pearl River delta, southern China, during the middle Holocene. Mar. Geol. 423, 106-133.

Fyfe, J. A., Selby, I. C., Shaw, R., James, J. W. C., and Evans, C. D. R. (1997). Quaternary sea-level change on the continental shelf of Hong Kong. J. Geol. Soc. 154, 1031-1038. doi: 10.1144/gsigs.154.6.1031

Guo, L. T., Wang, P., Zhang, K., Sheng, Q., Zhao, H., and Wang, C. M. (2013). OSL and $14 \mathrm{C}$ ages of the Late Quaternary sediments in the east Pearl River Delta. Geol. China 40, 1842-1849.

He, M., Zhuo, H. T., Chen, W. T., Wang, Y. M., Du, J. Y., Liu, L. H., et al. (2017). Sequence stratigraphy and depositional architecture of the Pearl River Delta system, northern South China Sea: an interactive response to sea level, tectonics and paleoceanography. Mar. Petrol. Geol. 84, 76-101. doi: 10.1016/j.marpetgeo. 2017.03.022 
Hori, K., Saito, Y., Zhao, Q. H., Cheng, X. R., Wang, P. X., Sato, Y., et al. (2001). Sedimentary facies and holocene progradation rates of the changjiang (Yangtze) delta, China. Geomorphology 41, 233-248. doi: 10.1016/s0169-555x(01) 00119-2

Hu, D. K., Clift, P., Böning, P., Hannigan, R., Hillier, S., Blusztajn, J., et al. (2013). Holocene evolution in weathering and erosion patterns in the Pearl River delta: weathering in holocene Southern China. Geochem. Geophys. Geosyst. 14, 2349-2368. doi: 10.1002/ggge.20166

Hua, Q., Webb, G. E., Zhao, J. X., Nothdurft, L. D., Lybolt, M., Price, G. J., et al. (2015). Large variations in the Holocene marine radiocarbon reservoir effect reflect ocean circulation and climatic changes. Earth Planet. Sci. Lett. 422, 33-44. doi: 10.1016/j.epsl.2015.03.049

Huang, C., Zeng, T., Ye, F., Xie, L. H., Wang, Z. B., Wei, G. J., et al. (2018). Natural and anthropogenic impacts on environmental changes over the past 7500 years based on the multi-proxy study of shelf sediments in the northern South China Sea. Q. Sci. Rev. 197, 35-48. doi: 10.1016/j.quascirev.2018.08.005

Huang, Z. G., Li, P. R., Zhang, Z. Y., Li, K. H., and Qiao, P. N. (1982). The Formation and Evolution of Pearl River Delta. Guangzhou: Science Populariazaiton Press.

Kong, D. M., Zong, Y. Q., Jia, G. D., Wei, G. J., Chen, M. T., and Liu, Z. H. (2014). The development of late holocene coastal cooling in the northern South China Sea. Q. Intern. 349, 300-307. doi: 10.1016/j.quaint.2013.08.055

Lai, Z. P. (2006). Testing the use of an OSL standardised growth curve (SGC) for De determination on quartz from the Chinese Loess Plateau. Rad. Measur. 41, 9-16. doi: 10.1016/j.radmeas.2005.06.031

Lai, Z. P. (2010). Chronology and the upper dating limit for loesssamples from Luochuan section in the Chinese Loess Plateau using quartz OSL SAR protocol. J. Asian Earth Sci. 37, 176-185. doi: 10.1016/j.jseaes.2009.08.003

Lai, Z. P., Mischke, S., and Madsen, D. (2014). Paleoenvironmental implications of new OSL dates on the formation of the "Shell Bar" in the Qaidam Basin, northeastern Qinghai-Tibetan Plateau. J. Paleolimnol. 51, 197-210. doi: 10. 1007/s10933-013-9710-1

Lai, Z. P., Zöller, L., Fuchs, M., and Brückner, H. (2008). Alpha efficiency determination for OSL of quartz extracted from Chinese loess. Rad. Measur. 43, 767-770. doi: 10.1016/j.radmeas.2008.01.022

Li, Y., Shang, Z. W., Tsukamoto, S., Tamura, T., Yi, L., Wang, H., et al. (2018). Quartz and K-feldspar luminescence dating of sedimentation in the North Bohai coastal area (NE China) since the late pleistocene. J. Asian Earth Sci. 152, 103-115. doi: 10.1016/j.jseaes.2017.10.036

Lin, J. X., Zhang, S. L., Qiu, J. B., Wu, B. Y., Huang, H. Z., Huang, H. Z., et al. (1989). Quaternary marine transgressions and paleoclimate in the Yangtze River delta region. Q. Res. 32, 296-306. doi: 10.1016/0033-5894(89) 90096-3

Liu, C. Y., Yin, J., Lian, L. C., Huang, Y., and Wu, Y. Q. (2016). Holocene mollusc records and palaeoenvironmental changes in the Pearl River delta. Trop. Geogr. 36, 355-363.

Liu, J., Yoshiki, S., Hong, W., Liang, Y. Z., and Zi, G. Y. (2009). Stratigraphic development during the Late Pleistocene and Holocene offshore of the Yellow River delta, Bohai Sea. J. Asian Earth Sci. 36, 318-331. doi: 10.1016/j.jseaes. 2009.06.007

Liu, Z. H. (1994). Neorectonics at the Pearl river mouth basin in South China Sea. Geol. Res. South China Sea 6, 30-50.

Liu, Z. H., Zhao, M., Sun, H. L., Yang, R., Chen, B., Yang, M. X., et al. (2017). "Old" carbon entering the South China Sea from the carbonate-rich Pearl River Basin: coupled action of carbonate weathering and aquatic photosynthesis Appl. Geochem. 78, 96-104. doi: 10.1016/j.apgeochem.2016.12.014

Murray, A. S., and Wintle, A. G. (2000). Luminescence dating of quartz using an improved single-aliquot regenerative-dose protocol. Rad. Measur. 32, 57-73. doi: 10.1016/s1350-4487(99)00253-x

Nageswara Rao, K., Saito, Y., Nagakumar, K. C. V., Demudu, G., Basavaiah, N., Rajawat, A. S., et al. (2012). Holocene environmental changes of the Godavari Delta, east coast of India, inferred from sediment core analyses and AMS14C dating. Geomorphology 175-176, 163-175. doi: 10.1016/j.geomorph.2012. 07.007

Nian, X. M., Zhang, W. G., Wang, Z. H., Sun, Q. L., and Hutchinson, S. M. (2018). The chronology of a sediment core from incised valley of the Yangtze River delta: comparative OSL and AMS14C dating. Mar. Geol. 395, 320-330. doi: 10.1016/j.margeo.2017.11.008
Owen, R. B., Neller, R. J., Shaw, R., and Cheung, P. C. T. (1998). Late Quaternary environmental changes in Hong Kong. Palaeogeogr. Palaeoclimatol. Palaeoecol. 138, 151-173. doi: 10.1016/s0031-0182(97)00129-6

Peng, Z. L., Chen, G. N., Grapes, P., Qiu, Y., Zhang, K., and Wang, J. (2014). Optically Stimulated Luminescence dating of sediments from the Pearl River delta, Southeast China. J. Earth Sci. Eng. 4, 378-384.

Pennington, B. T., Sturt, F., Wilson, P., Rowland, J., and Brown, A. G. (2017). The fluvial evolution of the holocene Nile Delta. Q. Sci. Rev. 170, 212-231. doi: 10.1016/j.quascirev.2017.06.017

Pleuger, E., Goiran, J. P., Mazzini, I., Delile, H., Abichou, A., Gadhoum, A., et al. (2019). Palaeogeographical and palaeoenvironmental reconstruction of the Medjerda delta (Tunisia) during the Holocene. Q. Sci. Rev. 220, 263-278. doi: 10.1016/j.quascirev.2019.07.017

Prescott, J. R., and Hutton, J. T. (1994). Cosmic ray contributions to dose rates for luminescence and ESR dating: large depths and long-term time variations. Rad. Measur. 23, 497-500. doi: 10.1016/1350-4487(94)90086-8

Reimer, P. J. (2014). Marine or estuarine radiocarbon reservoir corrections for mollusks? A case study from a medieval site in the south of England. J. Archaeol. Sci. 49, 142-146. doi: 10.1016/j.jas.2014.05.002

Reimer, P. J., Baillie, M. G. L., Bard, E., Bayliss, A., Beck, J., Bertrand, C. H., et al. (2004). IntCal04 Terrestrial radiocarbon age calibration, 0-26 cal kyr BP. Radiocarbon 46, 1029-1058. doi: 10.1017/s0033822200032999

Reimer, P. J., Bard, E., Bayliss, A., Beck, J. W., Blackwell, P. G., Ramsey, C. B., et al. (2013). IntCal13 and Marine13 radiocarbon age calibration curves 0-50,000 years cal BP. Radiocarbon 55, 1869-1887. doi: 10.2458/azu_js_rc.55.16947

Roberts, H. M., and Duller, G. A. T. (2004). Standardised growth curves for optical dating of sediment using multiple-grain aliquots. Rad. Measur. 38, 241-252. doi: 10.1016/j.radmeas.2003.10.001

Saito, Y., Yang, Z. S., and Hori, K. (2001). The Huanghe (Yellow River) and Changjiang (Yangtze River) deltas: a review on their characteristics, evolution and sediment discharge during the Holocene. Geomorphology 41, 219-231. doi: 10.1016/s0169-555x(01)00118-0

Sarkar, A., Sengupta, S., Mcarthur, J. M., Ravenscroft, P., Bera, M. K., Bhushan, R., et al. (2009). Evolution of ganges-brahmaputra western delta plain: clues from sedimentology and carbon isotopes. Q. Sci. Rev. 28, 2564-2581. doi: 10.1016/j.quascirev.2009.05.016

Shen, Z. X., and Mauz, B. (2012). Optical dating of young deltaic deposits on a decadal time scale. Q. Geochronol. 10, 110-116. doi: 10.1016/j.quageo.2012. 01.014

Song, Y., Lai, Z., Li, Y., Chen, T., and Wang, Y. (2015). Comparison between luminescence and radiocarbon dating of late quaternary loess from the Ili Basin in Central Asia. Q. Geochronol. 30, 405-410. doi: 10.1016/j.quageo.2015.01.012

Southon, J., Kashgarian, M., Fontugne, M., Metivier, B., and Yim, W.-S. W. (2002). Marine reservoir corrections for the Indian Ocean and Southeast Asia. Radiocarbon 44, 167-180. doi: 10.1017/s0033822200064778

Stanley, D. J., and Chen, Z. Y. (2000). Radiocarbon dates in China's Holocene Yangtze delta: record of sediment storage and reworking, not timing of deposition. J. Coast. Res. 16, 1126-1132.

Sugisaki, S., Buylaert, J. P., Murray, A., Tada, R., Zheng, H., Bo Ke, W., et al. (2015). OSL dating of fine-grained quartz from Holocene Yangtze delta sediments. Q. Geochronol. 30, 226-232. doi: 10.1016/j.quageo.2015. 02.021

Tang, C., Zhou, D., Endler, R., Lin, J. Q., and Harff, J. (2010). Sedimentary development of the Pearl River Estuary based on seismic stratigraphy. J. Mar. Syst. 82, S3-S16.

Wang, F., Nian, X. M., Wang, J. L., Zhang, W. G., Peng, G. Y., Ge, C., et al. (2018). Multiple dating approaches applied to the recent sediments in the Yangtze River (Changiiang) subaqueous delta. Holocene 28, 858-866. doi: 10.1177/ 0959683617752847

Wang, Z. H., Saito, Y., Zhan, Q., Nian, X. M., Pan, D. D., Wang, L., et al. (2018). Three-dimensional evolution of the Yangtze River mouth, China during the holocene: impacts of sea level, climate and human activity. Earth Sci. Rev. 185, 938-955. doi: 10.1016/j.earscirev.2018.08.012

Wang, F., Zhang, W. G., Nian, X. M., Ge, C., Zhao, X. Q., Cheng, Q. Z., et al. (2019). Refining the late-Holocene coastline and delta development of the northern Yangtze River delta: combining historical archives and OSL dating. Holocene 29, 1439-1449. doi: 10.1177/0959683619854522 
Wei, X., Mo, W. J., and Wu, C. Y. (2011). Analysis on the sedimentation rates and depositional environment of the Pearl River delta Area since Holocene. Acta Sedimentol. Sin. 29, 329-335.

Wu, M. S., Zong, Y. Q., Mok, K. M., Cheung, K. M., Xiong, H. X., and Huang, G. Q. (2017). Holocene hydrological and sea surface temperature changes in the northern coast of the South China Sea. J. Asian Earth Sci. 135, 268-280. doi: 10.1016/j.jseaes.2017.01.004

Xiong, H. X., Zong, Y. Q., Qian, P., Huang, G. Q., and Fu, S. (2018). Holocene sealevel history of the northern coast of South China Sea. Q. Sci. Rev. 194, 12-26. doi: 10.1016/j.quascirev.2018.06.022

Xu, K. H., Li, A. C., Liu, J. P., Milliman, J. D., Yang, Z. S., Liu, C.-S., et al. (2012). Provenance, structure, and formation of the mud wedge along inner continental shelf of the East China Sea: a synthesis of the Yangtze dispersal system. Mar. Geol. 291-294, 176-191. doi: 10.1016/j.margeo.2011. 06.003

Xu, Y. T., Lai, Z. P., and Li, C. A. (2019). Sea-level change as the driver for lake formation in the Yangtze plain - a review. Glob. Planet. Chang. 181:102980. doi: 10.1016/j.gloplacha.2019.102980

Yao, Y. T., Zhan, W. H., Liu, Z. F., Zhang, Z. Q., and Zhan, M. Z. (2008). Neotectonics of the Pear River delta and its relationship with the deltaic evolution. South China J. Selsmol. 28, 29-40.

Ye, L. T., Yu, G., Liao, M. N., Hu, S. Y., Wang, L. S., and Gao, L. (2017). Terrestrialmarine sedimentary cycles in the South Yellow Sea, China: implications for paleoenvironmental reconstruction since MIS 5. Turk. J. Earth Sci. 26, 170-188. doi: 10.3906/yer-1608-18

Yi, L., Lai, Z. P., Yu, H. J., Xu, X. Y., Su, Q., Yao, J., et al. (2013). Chronologies of sedimentary changes in the south Bohai Sea, China: constraints from luminescence and radiocarbon dating. Boreas 42, 267-284. doi: 10.1111/j.15023885.2012.00271.x

Yim, W. W. S., Huang, G., Fontugne, M. R., Hale, R. E., Paterne, M., Pirazzoli, P. A., et al. (2006). Postglacial sea-level changes in the northern South China Sea continental shelf: evidence for a post- 8200 calendar yr BP meltwater pulse. Q. Intern. 145-146, 55-67. doi: 10.1016/j.quaint.2005.07.005

Yim, W. W. S., Ivanovich, M., and Yu, K. F. (1990). Young age bias of radiocarbon dates in pre-holocene marine deposits of Hong Kong and implications for pleistocene stratigraphy. Geo Mar. Lett. 10, 165-172. doi: 10.1007/bf020 85932
Yin, J., Liu, C. L., Wu, J., Huang, Y., and Wu, Y. Q. (2016). Foraminiferal records and palaeoenvironmental changes since the late pleistocene in central Pearl River Delta. J. Palaeogeogr. 18, 677-690.

Yu, S. Y., Colman, S. M., and Lai, Z. P. (2019). Late-Quaternary history of 'great lakes' on the Tibetan Plateau and palaeoclimatic implications - A review. Boreas 48, 1-19. doi: 10.1111/bor.12349

Yu, Z. X. (2017). The Age of the Lower Transgression Cycle in the Pearl River Delta and Its Implication of Sea-Level Changes and Neotectonic Movements. Ph. D. thesis, Sun Yat-sen University, Guangzhou.

Yu, Z. X., Zhang, K., Li, X. Y., Liang, H., and Li, Z. Y. (2017). The age of the old transgression sequence in the Pearl River delta, China. Acta Geol. Sin. 91, 1515-1516. doi: 10.1111/1755-6724.13388

Yu, Z. X., Zhang, K., Liang, H., and Li, Z. Y. (2016). Late quaternary tectonic movements in the Pearl River delta, china, revealed from stratigraphic profiles. Trop. Geogr. 36, 334-342.

Zhou, K. E., Xu, H., Lan, J. H., Yan, D. N., Sheng, E. G., Yu, K. K., et al. (2020). Variable late Holocene 14C reservoir ages in Lake Bosten, Northwestern China. Front. Earth Sci. 7:328. doi: 10.3389/feart.2019.00328

Zong, Y. Q. (2004). Mid-Holocene sea-level highstand along the Southeast Coast of China. Q. Intern. 117, 55-67. doi: 10.1016/s1040-6182(03)00116-2

Zong, Y. Q., Huang, G. X., Switzer, A. D., Yu, F. L., and Yim, W. W. S. (2009a). An evolutionary model for the holocene formation of the Pearl River delta, China. Holocene 19, 129-142. doi: 10.1177/0959683608098957

Zong, Y. Q., Yim, W. W. S., Yu, F. L., and Huang, G. Q. (2009b). Late Quaternary environmental changes in the Pearl River mouth region, China. Q. Intern. 206, 35-45. doi: 10.1016/j.quaint.2008.10.012

Conflict of Interest: The authors declare that the research was conducted in the absence of any commercial or financial relationships that could be construed as a potential conflict of interest.

Copyright (c) $2020 \mathrm{Xu}, \mathrm{Li}$, Tang, Lai, Xu, Zhang and Wang. This is an open-access article distributed under the terms of the Creative Commons Attribution License (CC BY). The use, distribution or reproduction in other forums is permitted, provided the original author(s) and the copyright owner(s) are credited and that the original publication in this journal is cited, in accordance with accepted academic practice. No use, distribution or reproduction is permitted which does not comply with these terms. 